Commentary

\title{
High-risk diabetic pregnancy and work: two hard-to-reconcile circumstances ${ }^{1}$
}

\author{
Janine Schirmer ${ }^{2}$
}

\begin{abstract}
In 1991 the prevalence of diabetes was 7.6\% in women in nine Brazilian state capitals. This disease now ranks among the leading causes of death in the country and is becoming an increasingly alarming public health problem. In spite of advances in the treatment of diabetes and improved obstetric care, gestational diabetes puts a pregnant woman at high risk of miscarriage, ketoacidosis, hypoglycemia, hypertension, and other serious disorders. This study used life histories to investigate the relationship between health, sexuality, and work in five working women who were diabetic and pregnant and who received care at the Prenatal Care Outpatient Clinic of the San Pablo Hospital. These women all had non-insulin-dependent diabetes mellitus, were between 26 and 43 years old, and earned from US\$ 150 to US\$ 375 per month for working 8-hour days, with one day off each week. Two of the women's male partners were unemployed; all of the women performed household chores during their day off. Quotations taken directly from conversations with the five participants reveal the difficulty of caring for children while holding down a job; the sexual harassment that some of the women suffered; the conflict and dissatisfaction associated with work; the myth of the natural joy of motherhood; the sexual control exercised by males; the incompatibility of working conditions and work activities with pregnancy; and the perception that they did not have legal protection owing to employers' lack of respect for workers' rights and for the maternity protection provisions of the Federal Constitution of Brazil. It is concluded that health policies should pay greater attention to improving the quality of life of working women, especially if they suffer from diabetes and are pregnant.
\end{abstract}

The group of interviews reported here were motivated by the author's professional experience as an obstetric nurse in an outpatient clinic located in São Paulo, Brazil, that provides prenatal care to women with high-risk pregnancies, primarily women with diabetes. More specifically, the study

\footnotetext{
A Spanish version of this article has previously been published in this journal (Vol. 1, No. 3, pp. 235-240) under the title "Trabajo y gestación de alto riesgo por diabetes: dos circunstancias difíciles de conciliar."

2 Federal University of São Paulo, Department of Nursing, Rua Napoleão de Barros, 754, CEP 04024002 São Paulo, SP, Brazil. E-mail (Internet): janine.den@epm.br
}

was motivated by nine years of experience living and working with these patients and by firsthand knowledge of the difficulties they experienced in trying to reconcile work with high-risk pregnancy, often because their rights as employees were disrespected or ignored. It is well known that stress, anxiety, and fear of losing one's job make metabolic control of diabetes more difficult and can lead to deterioration not only of a pregnant woman's health but also of her pregnancy's prognosis.

These concerns led me to explore how women in my part of the world perceive their rights as employees dur- ing pregnancy and motherhood. There is no doubt that these perceptions, besides influencing clinical-obstetric care, also influence care while the child is nursing. This latter care involves a mother-child relationship in which not only knowledge but also feelings are shared. For this reason, it is essential that examination of this subject include women's subjective views, regarding both caring for others and acquisition of knowledge about health and disease.

The epidemiology of diabetes in Brazil underscores the importance of this matter. The National Diabetes Census of 1991 conducted by the Min- 
istry of Health among urban population groups in nine state capitals recorded diabetes prevalences of $7.6 \%$ for women and $7.5 \%$ for men. As is well known, diabetes constitutes a serious public health problem, because the syndrome's degenerative complications-primarily retinopathy, nephropathy, and neuropathy-commonly lead to deterioration in the diabetic's quality of life, frequently disabling the patient and shortening his or her life expectancy.

The prevalence of diabetes in Brazil has risen considerably in recent decades, increasing both the socioeconomic repercussions (resulting from incapacitation and premature death) and the costs associated with control and treatment of the disease's acute and chronic-degenerative complications. By 1982 diabetes already ranked among the primary causes of death in Brazil, accounting for 9.4 deaths per 100000 individuals and $1.6 \%$ of all deaths in the country. Within this context, it is noteworthy that cardiovascular disease is three times more frequent in diabetics than nondiabetics, and that peripheral vasculopathy appears in approximately $10 \%$ of all diabetics as compared to only $2.6 \%$ of the nondiabetic population. Diabetes is also the primary cause of acquired blindness and the second leading cause of terminal nephropathy, being found in approximately $20 \%-25 \%$ of these clinical pictures.

Pregnant women with a prior diagnosis of diabetes or one detected during pregnancy are deemed to have high-risk pregnancies. Despite the fact that advances in diabetic, obstetric, and neonatal care have led to improved perinatal and maternal outcomes, gestational diabetes still has the potential to produce severe complications. The most frequently occurring maternal complications are spontaneous abortion, ketoacidosis, hypoglycemia, hypertension, pyelonephritis and other infections, polyhydramnios, premature delivery, and exacerbation of diabetes-related chronic vascular problems. Morbidity and mortality among newborns of diabetic mothers are commonly related to high incidences of congenital malformations, fetal gigantism, metabolic disorders, and respiratory distress syndrome.

\section{METHODOLOGY}

In studying the relationship between work and high-risk pregnancy, one starts with a special view of the maternal experience-because this experience must be considered in conjunction with the impact the job has upon the working woman in terms of energy consumption, bodily alterations, modification of social relationships, and imposition of a need to devote additional time and attention to the pregnancy in order to bring it to a satisfactory outcome. In this context, the Federal Constitution of Brazil of 1988 guarantees both urban and rural workers maternal and paternal rights; but it is still essential for working women to know about labor legislation so that they can demand their rights as workers as well as be aware of their obligations.

The study reported here was conducted using a multidisciplinary approach that took in the fields of obstetric nursing, epidemiology, and health sociology. The study consisted of qualitative research based on the life histories of a small number of diabetic women, the reported information being obtained through interviews. Research of this sort, using the methods of anthropology and sociology, permits examination at considerable depth of the subject at hand, together with the complex of factors relating health, sexuality, and work. The approach used here encouraged creation of a bond of trust and reflection between the researcher and the women participating in the study in a manner encouraging them to identify with the phenomenon being studied.

Two criteria were used to select study subjects: the individuals had to be formally employed in some fashion and had to be diabetic pregnant women seen at the Outpatient Prenatal Care Unit of the São Paulo Hospital during the six-month study period. Five women satisfied these criteria.
The five study subjects had noninsulin-dependent (type II) diabetes mellitus, in which few or no metabolic symptoms are present. Such patients do not require insulin to prevent ketonuria and are not prone to ketosis. They may, however, need insulin to correct certain symptoms of persistent hyperglycemia.

Interviews were used to obtain information about each woman's sociodemographic profile, the various forms of control found in the workplace, sexual harassment in the workplace, health, sexuality, reproductive life, and the relationship between work and high-risk pregnancy. All the interviews were recorded on audio cassettes. Conducted anonymously, their audio dialogue provided information for subsequent analysis.

\section{FINDINGS}

\section{Sociodemographic profile}

The ages of the five subjects ranged from 26 to 43 years. Two were married (one for 15 years, the other for 23); the other three had been living in free unions for a minimum of 9 years. Three were illiterate and had not completed first grade. Four worked for restaurants, cleaning services, or private homes, while the fifth was employed selling clothes in a shopping center. All had obtained the required work permit more than a year before the study and met the legal requirements for participating in the formal labor market. The laws of Brazil (Consolidated Labor Laws) refer to this category of worker as an "employee ... who works for an individual or firm for a period of time in exchange for a salary."

The monthly salaries of the five subjects ranged from US\$ 150 to US\$ 375; their work days lasted eight hours, and they received one day off a week. One of the married subjects' husbands and one of the unmarried subjects' partners were unemployed.

Domestic housework was an integral part of all five subjects' activities. That is, all performed domestic chores 
in their homes, primarily on their day off, almost always assisted by their mothers and older daughters: ${ }^{3}$

My mother lives with me and helps me, but I do the heavy work in the house on Monday, my day off (1).

My 17-year-old twin girls perform the household chores. I only prepare meals, when I arrive home from work (3).

Only one of the women left her youngest daughter in a day-care center; the others left their children with older siblings or alone:

I do all of the work in the house. I have a 2-year-old daughter who stays at home with my oldest daughter, who is 17 (4).

I do all the work in the house. I don't trust my 14-year-old daughter, who has epileptic seizures. I used to leave my 2-year-old daughter in the day-care center, but it seems I lost that right, so now I pay a woman to take care of her, because I cannot leave her with my oldest daughter (5).

This latter statement demonstrates the difficulty of caring for children and working, as well as this mother's feeling of lack of protection, because her notion of her "right" is very fragile.

\section{Control and sexual harassment in the workplace}

When the study women were asked if they felt controlled at work, only one responded that she was not controlled, as indicated below:

No, because my boss is a friend and neighbor. She opened a cafeteria, and I agreed to help her prepare lunch. No one checks when I leave work, and I have no problems with my lunch hour (3).

Three of the women pointed out specific ways in which they were controlled at work. Two examples:

\footnotetext{
In the passages quoted from the interviews, each of the five study subjects is identified by a number from one to five that is included in parentheses at the end of the passage.
}

Yes, there is a supervisor who never stops talking. There is control over coming in and leaving. My boss is a man (4).

They control everything. If you talk while washing dishes, they yell at you, "Get to work!" There are 11 of us women in the kitchen (5).

One of the study subjects did not feel that she was subject to controls. Rather, this woman reported that she exercised control over her female coworkers. It could be seen from the way she spoke that the responsibility her boss delegated to her made her value her work more:

No one controls me; on the contrary, it is I who control the waitress and the woman who does the cleaning. I am in charge of shopping for the house. If, for example, I need to leave work early one day, for any reason, I don't ask permission from the owner, who is a nuisance, but rather from his wife, you know, the one who pays my salary (3).

Checking bags and packages at the end of a shift, restrictions on use of the toilet, and failure to respect the designated lunch hour are customary in the Brazilian labor environment.

They check our bags when we leave work. Lunch break lasts for one hour, from 11 to $12 \mathrm{o}^{\prime}$ clock in the morning. I take food from home (4).

The Federal Constitution of Brazil guarantees time for resting or eating: "An employee who works for a period of 6 continuous hours is entitled to a minimum of one hour to rest or eat." However, the interviews conducted with the study women provided evidence of the frequent failure to observe this guarantee:

A set time to eat lunch? No, I eat lunch behind the counter, during the interval between one client and the next, and the food gets cold (1).

No one checks us when we leave work, but all bags must be kept in the bathroom. When someone has to go to the bathroom a second time, that's when the problems start. Sometimes I couldn't go even once, not even when I had my period. There was no break for lunch; I ate at four o'clock in the afternoon, when we were given a short 10- or 15-minute break. Since I am diabetic and have to take insulin, I can't go without eating. When they hired me, they knew about my illness (5).

Sexual harassment is no longer a socially ignored form of abuse, though it frequently goes unreported in the working environment, almost always to avoid the risk of losing one's job. In this vein, while all the study women had witnessed instances of sexual harassment, none knew whether the victims had reported their cases. Furthermore, the study women themselves frequently judged the victims to be guilty of bringing on such treatment, in accordance with the saying that "if a woman acts correctly, no man will misbehave." As one study subject put it,

I saw sexual harassment almost everywhere I worked, but it is the woman's fault; lots of them like that. They ask you out, tell you jokes . . . I think it depends on the woman. Most of them go out with men. If that happened to me, I would tell my boss (4).

However, the study subjects also reported that they were not victims of sexual harassment in their workplaces. For example:

My boss travels, and I stay at home alone with her husband and her 19-year-old son, and neither of them has ever been disrespectful to me (3).

\section{Health}

The subjects perceived diabetes as a disruptive force in their lives, as something both bad and serious:

After I got diabetes, my health became complicated (1).

It seems my health was not as good as I thought it was. Some little problems began to appear... diabetes (2).

My health was neither good nor bad. It was only after this diabetes that my health ceased to be good (4). 
One of the women related the loss of her "good health" to her arrival in São Paulo and her employment:

I was all right until 1988, when I gained weight and my blood pressure went up. Before, I would work in the field, I was thin, and I had three children with no problems. After coming to São Paulo nine years ago, my health deteriorated. I think it must have been because of work, because I am a very nervous person; I like things to be nice and orderly; I don't want the boss to be criticizing my work. I used to weigh 53 kilos, but now I weigh 90 (3).

Motherhood has a strong impact on the social position accorded to women. Pregnancy is considered socially to be a "state of grace," and statements to the contrary are rarely admitted. However, in the comments made during the interviews, the women frequently questioned the myth of the "natural joy" of motherhood as compared to work as an element of conflict and dissatisfaction. Pregnancy is seen as a factor leading to deterioration of one's health status, primarily in the case of high-risk pregnancies.

The only thing that represents a complication is pregnancy, and more so with diabetes, which has to be controlled (1).

My health problems began after I gave birth by cesarean section, not because of the operation itself but rather because of the anesthesia and now because of the pregnancy (4).

The women interviewed also reported a positive relationship with their work, perhaps as a form of escape from the confinement of their domestic environs. For example:

I have been working outside the home for a long time. It is good for me to work because I enjoy myself, I escape from my routine, I feel good (5).

When asked if there were any health problems that limited their daily activities, some subjects mentioned pregnancy as a source of physical problems. For instance:

Sometimes I get a backache that leaves me unable to move. Once the boss got up at dawn and gave me an injection for pain. Now, with the pregnancy, I am worse (3).

\section{Sexuality}

The study women's perception of sexuality was heavily colored by matters related to reproduction and the notion that conjugal fidelity is an obligation of the wife. Control over sexuality and reproduction is exercised by the husband, as a masculine and hierarchic cultural feature of power over women. Some women who indicated that they had a permanent sexual partner reaffirmed their female fidelity and their trust in male fidelity, leaving no room for doubt about the nature of the relationship or the possibility of dialogue or any form of negotiation:

No. For now, he does not have another woman, although he used to have one. During an earlier pregnancy we separated (1).

My husband is my only sexual partner and I am his only woman (2).

Just as pregnancy was considered by the study women as a factor contributing to deterioration of their physical health, so their sexual life during pregnancy was seen as leading to deleterious effects including depression, anxiety, anger, conflict, and family disruption:

Every time I get pregnant, we separate and we quarrel. When I'm not pregnant, we have sex three or four times a week, but during pregnancy we go 30 days without doing anything. He doesn't seek me; I need to insist, but even so it's something cold, and I cry and feel despair. Since we already separated before and he sought another woman, I am now even more upset; this worries me constantly. When I was eight months pregnant, I even gave a beating to the woman who was with him, who was living across the patio we shared (1).

My sex life changed after pregnancy, because I didn't want to have any more children. It was an unwanted pregnancy, and if he now feels rejected, I am very sorry, but I didn't want it. I'm not happy to be like this. Now when he comes close to me, I feel repulsion. Sometimes when I'm at home, he comes to me and I get that nausea again. He comes close and I tell him to go away, that I don't want to have anything to do with him (5).

When work was considered the cause of disruption in a study woman's sex life, that disruption was described in terms of unfavorable conditions and fatigue, as opposed to illness:

Neither pregnancy nor work interfere in our sex life, because we only see each other on weekends (3).

Work interferes with sex life as a result of fatigue. On some days I arrive home so tired that I can hardly feed the children and don't want to do anything but go to bed (4).

All of the women interviewed had used some contraceptive method. Nevertheless, considering that all had experienced more than three deliveries, many of these while adolescents, it appears that use of contraception was quite irregular or without the benefit of appropriate professional advice:

I took pills and got pregnant while using an IUD (3).

I used injections for eight years, and then pills and condoms (4).

I took [brand name of a contraceptive] for seven years, before I knew that I had diabetes. Then I started using condoms, but they produced an allergic reaction in my vagina and the physician recommended that I not use them. My husband was exercising caution. I couldn't get an appointment at the family planning center because they were all filled up (5).

\section{Reproductive life}

The five women interviewed had their initial pregnancies between the ages of 15 and 21. Their reproductive history was characterized by large numbers of pregnancies, abortions, 
and premature deliveries; short times between pregnancies; pregnancyrelated disorders such as hypertension, obesity, and diabetes; and health care that was almost always inadequate with regard to pregnancy, childbirth, and the postpartum.

The reproductive history of woman No. 1 was characterized by several miscarriages, probably the result of heavy and exhausting domestic chores that she performed, as well as by problems involving health care and lack of information about the various risk factors that can lead to premature delivery.

During my first pregnancy, I received prenatal check-ups in a basic health care unit. I didn't work outside the home but I did wash clothes. I had to go up onto the roof to hang up the clothes, and one day when I went up onto the roof I started to hemorrhage and lost my baby. In my second pregnancy, I had twins. I also received prenatal check-ups at the health post, in addition to which the exams were performed in a better hospital. But I didn't know that I had to take care of myself; I worked as a cashier in a grocery store, and in my sixth month I started to feel pains. I didn't know that they were labor pains. For six hours I had colic; I began to bleed and broke my water. I went to the hospital; two babies weighing a half-kilo each were born, but neither survived.

During my third pregnancy I had prenatal check-ups here in the São Paulo Hospital, in the miscarriage-prone unit. At 32 weeks I felt contractions, so I was hospitalized for three days and was given serum to prevent labor. They performed fetal monitoring, and in one exam they were able to see that the baby's heart was beating very slowly. They performed an emergency C-section. At that time, the diabetes had already showed up and I was taking insulin. The baby lived for only two days. I really wanted my current pregnancy, but the possibilities for survival of the baby are minimal as a result of the seriousness of my diabetes, the presence of anti-phospholipid antibodies, and hypertension (1).

Woman No. 3 first had a simple pregnancy followed by a twin pregnancy. The delivery took place at home, in a rural area, with no problems:
Afterwards, I came to live in São Paulo with this man and I had a third pregnancy that ended in a provoked abortion. I didn't want to have a child living in my employer's house. My husband looked for a job; we didn't have a house to live in. My employer paid for the abortion in the clinic; they gave me anesthesia, but I felt a lot of pain. I had to rest for two days. My head was all right, because I was worried about my children who were in Bahia . . . I couldn't afford to have any more children (3).

This narrative is illustrative of abortion as something used to protect living children by keeping one's job. Another issue is the ambivalence of the solidarity shown by the employer who pays for the abortion, thus ensuring that the employee will remain at work and avoiding any additional expenses as a consequence of the pregnancy.

In my fourth pregnancy I suffered a miscarriage, and now I have this diabetes that they discovered three years ago. The sonogram showed that the baby had a hare lip (3).

\section{Work and high-risk pregnancy}

Overall, the five study women reported a lack of stimulus at work and lack of recognition by their employers with regard to their needs for prenatal care. Work-related activities and conditions tended to interfere with proper prenatal care, a situation exacerbated by the women's lack of knowledge of their rights during pregnancy. From an ethical standpoint, these issues unquestionably need to be addressed by health professionals. The following comment illustrates the difficulty:

Work interferes with my pregnancy. In order to go for my check-up, I told my employer that I couldn't go to work on Wednesday. Where I work it is very hot; it is very hard for me, as I am on my feet all day long and have no time to go to the bathroom. I don't receive any extra pay for working in an unhealthy atmosphere, nor have I ever done so. At the shopping center, you can count on the fingers of one hand the number of employees who are legally registered to work. They work from 10 o'clock in the morning straight through until
10 o'clock at night, and they are not registered. My employer reminds me of this every day, telling me that I should be happy because I am registered (1).

Brazilian legislation defines an unhealthy workplace as "a place that can be harmful to health-for example, places exposed to heat, cold, dust, noise, etc." The comments provided by the study women referred to such conditions. For example:

I began to work during the last of my three pregnancies. It is very hard for me to work while I'm pregnant. The work is very heavy; I have to walk a lot, and at the end of the day my feet are swollen and I have abdominal pain. In this job they allow me to go for my check-ups, as long as I bring a statement from the doctor and don't miss work; since we are only four women, if one of us doesn't show up, it disrupts the work of the other three. I know that I have a highrisk pregnancy; I already told my boss that I may need to be hospitalized, but I don't think that I'm going to have any problems (4).

Protection for maternity was expanded in the Brazilian Constitution promulgated in 1988. Previously, employees were entitled to 90 days of pregnancy or maternity leave. The 1988 Constitution (Art. 7, paragraph XVIII) extended that leave to 120 days with pay. The following comment by woman No. 5 illustrates how labor legislation guaranteeing the right to maternity leave is frequently not observed.

My first job as a legally registered employee was during my first pregnancy, when they began to take off from my salary for the days when I went for prenatal check-ups and testing. At that point I began to take a doctors' certification to work and they stopped deducting from my salary. They gave me maternity leave, but they deducted the corresponding payment and the transportation subsidy. They said that I was no longer there to sign the receipt and that they couldn't give the money to my husband. When I went back to work I had to sue them in order to get paid (5).

According to the Constitution and the Consolidation of Labor Laws (Art. 
476), an employee may not be fired from the time when her pregnancy is confirmed until five months following delivery or at any time during her period of health care leave. As the comments of woman No. 5 again bring out, these rights are frequently not respected in practice:

During my last pregnancy I had problems at work. I was fired because I was hospitalized for five days. They told me that they couldn't continue to employ someone who is sick as a result of a highrisk pregnancy. They didn't have any problems with the diabetes, only with the pregnancy (5).

Women should be informed, during pregnancy and the postpartum, of their rights as workers, and especially of their rights with regard to maternity, by the various health professionals responsible for providing them with care. The diabetics in our sample received information about their right to maternity leave only through informal conversations with other pregnant women, usually coworkers:

Nobody spoke to me about the rights of pregnant women, either here or at the prenatal check-up. When a woman asks for a medical certificate, they tell you that they can't give you one, not even when you are hospitalized. According to their law, the birth declaration or certificate is not worth anything; the only thing that is worth anything is the discharge statement. When you ask for a declaration, they don't pay any attention to you (5).
Sexuality can sometimes serve as a means of controlling workers' behavior. The following statement by woman No. 3 illustrates this point.

I don't know what maternity leave is. I've heard of it, but nobody has ever explained it to me. My employer told me that I have a right to such leave, but first she threw out a few hints about getting an abortion. I didn't want to do that. My husband has other children, but this is his first with me (3).

According to the Federal Constitution (Art. 7, Par. XIX), the man has a right to five days of paternity leave, beginning on the date when the baby's birth certificate is submitted to the employer. Comments provided by two of the study women reflect a failure by companies to comply with the law and workers' lack of awareness of their rights:

I didn't know that the father has a right to paternity leave (1).

I didn't know that the husband has a right to leave. My husband was laid off from work for eight days because he didn't go to work on the day my baby was born (5).

\section{CONCLUDING REMARKS}

This study points up a number of matters that need to be addressed by health policies in order to improve the quality of life of working women, especially those who are diabetic.

\section{BIBLIOGRAPHY}

American Diabetes Association. Medical management of pregnancy complicated by diabetes. New York: ADA; 1993.

Brasil, Ministério da Saúde, Secretaria Nacional de Assistência à Saúde da Mulher, Divisão Nacional da Saúde Materno Infantil, SubPrograma de Assistência Integral à Saúde da Mulher. Gestação de alto risco. Brasília: MS; 1991.

Brasil, Ministério da Saúde, Secretaria de Assistência à Saúde, Departamento de Assistência e Promoção à Saúde, Coordenação de Doenças Crônico-Degenerativas. Manual de diabetes, 2nd ed. Brasília: MS; 1993.

Bruschini MCA. Mulher, casa e família: cotidiano nas camadas médias paulistanas. Vértice: Fundação Carlos Chagas-Editora dos Tribunais; 1990.
Centro Feminista de Estudos e Assessoria. Guia dos Direitos da Mulher. Brasilia: CFEA; 1994.

Instituto de Estudos da Religião (ISER). Programa nario de Teologia e Direitos Reprodutivos. Petrópolis, RJ: ISER; 1994.

Minayo MCS. O desafio do conhecimento: pesquisa qualitativa em saúde. São Paulo/Rio de Janeiro: Hucitec-Abrasco; 1992.

Oliveira ME, Storti R, Carneiro F. Gênero, saúde e trabalho: a dimensão oculta. São Paulo: Editora do Sindicato dos Bancários de São Paulo; 1996.

Romito P. Lavoro e salute in gravidanza: come la società si prende cura delle donne incite. Milan: Franco Angeli; 1990. Sofia: mulher, teologia e cidadania. III Semi-
Commonly, diabetic women who become pregnant feel doubly blamed-on the one hand, for having a disease that stigmatizes them socially as unable to enjoy a normal sexual and reproductive life; and, on the other, for having become preg-nant while diabetic. The demands of the working world penalize them harshly. They go through their pregnancies in a state of permanent stress from the fear of losing both their baby and their job. Not surprisingly, this can lead to neglect of their own health as well as to depression, low self-esteem, and despair. For some of these diabetic women, the possibility of a new pregnancy is cause for panic. In addition, the burden of work added to household duties compounds perinatal risk.

Interview comments about the study subjects' relationships with their health professionals and employers frequently indicated problems involving discrimination and denial of women's rights. In the case of health professionals, difficulties often arise because the individuals involved lack preparation to deal with the complex problems facing these women, which tend to extend well beyond the clinical scenario of the disease. Businesses and private employers take advantage of an existing lack of enforcement as well as of workers' lack of knowledge of their rights.
Schirmer J. Participação da enfermeira obstetra na equipe de assistência à gestante diabética. (Master's thesis). São Paulo: Escola Paulista de Medicina; 1989.

Schirmer J. Fatores de risco para o desenvolvimento de diabetes mellitus após diabetes diagnosticado na gravidez. (Doctoral thesis). São Paulo: Universidade Federal de São Paulo; 1995.

World Health Organization. Diabetes mellitus: report of a WHO study group. Geneva: WHO; 1985. (Technical Report Series, 727).

Manuscript received on 26 June 1996. Accepted for publication on 10 July 1996. 
RESUMEN En 1991, la prevalencia de diabetes en mujeres de nueve capitales brasileñas era de $7,6 \%$. Esta enfermedad ya consta entre las principales causas de defunción en ese país y se está convirtiendo en un problema de salud pública cada vez más alarmante. A

Trabajo y gestación de alto riesgo por diabetes: dos circunstancias difíciles de conciliar pesar de los avances en el tratamiento de la diabetes y una mejor atención obstétrica, la diabetes gestacional pone a la embarazada en alto riesgo de aborto espontáneo, cetoacidosis, hipoglucemia, hipertensión y otros trastornos graves. En este estudio se investigaron mediante historias de vida las relaciones entre salud, sexualidad y trabajo en cinco trabajadoras diabéticas embarazadas atendidas en el Ambulatorio de Atención Prenatal del Hospital San Pablo. Todas tenían diabetes mellitus no insulinodependiente, entre 26 y 43 años de edad y ganaban de US\$ 150 a 375 por 8 horas de trabajo diario, con un descanso semanal. Dos tenían compañeros desempleados; todas realizaban las tareas domésticas del hogar durante el día de descanso. Las citas tomadas directamente de conversaciones con las cinco participantes revelan la dificultad de cuidar a los hijos y también trabajar; el acoso sexual de que algunas son objeto; el trabajo como elemento de conflicto e insatisfacción; el mito de la felicidad natural de la maternidad; el control sexual que ejerce el hombre; la interferencia de las condiciones de trabajo y la actividad laboral con la gravidez, y la sensación de que están legalmente desamparadas debido a la falta de respeto de los empleadores por los derechos laborales y la protección de la maternidad que establece la Constitución Federal del Brasil. Se concluye que en las políticas de salud debe prestarse atención a mejorar la calidad de vida de las mujeres trabajadoras, especialmente si padecen diabetes y están embarazadas.

\section{5. ${ }^{0}$ Simposio Internacional de Puijo}

Fechas: 22 a 25 de junio de 1998

Lugar: Kuopio, Finlandia

Tema: La actividad física en la prevención y el tratamiento de la obesidad y de sus trastornos metabólicos asociados

El Instituto de Kuopio para la Investigación sobre el Ejercicio en la Medicina (Kuopio Research Institute of Exercise Medicine) es la entidad que patrocina este simposio sobre las aplicaciones terapéuticas de la actividad física en pacientes con obesidad y trastornos subyacentes del metabolismo.

Información:

Kuopio Research Institute of Exercise Medicine

Haapaniementie 16, FIN-70100 Kuopio

Tel.: (358) 172884422

Fax: (358) 172884488

Correo electrónico: puijo.symposium@uku.fi 